\title{
Quality Management Education in the Industrial Revolution Era 4.0 and Society 5.0
}

\author{
Darmaji \\ Education Management Postgraduate \\ Universitas Negeri Malang, Indonesia \\ ajidarmaji64@gmail.com
}

\author{
Mustiningsih \\ Department of Educational Administration \\ Universitas Negeri Malang, Indonesia \\ Mustiningsih.fip@um.ac.id
}

\author{
Imron Arifin \\ Department of Educational Administration \\ Universitas Negeri Malang, Indonesia \\ Imron.arifin.fip@um.ac.id
}

\begin{abstract}
The writing of this article aims to determine quality management through the concept of educational quality, the concept of standard quality of education in the Industrial Revolution 4.0 and society 5.0. it will change the human order both the way of life, the way to communicate, how to interact and how to receive information with the emergence of smartphones, the internet and which is everything done by machines. The industrial revolution has been transformed from workings of humans into automation or digitization through an innovation. The 4.0 industrial revolution will bring many changes with all the consequences, an influential change in life, where's human and animal power is replaced by machines. At the moment we are preparing to leave the industrial era 4.0 towards the era of society 5.0 human beings are entering the phase of the super smart society era, where all sensing technology, robotics, communication, big data, and computing. Data is a very important role in people's lives 5.0.
\end{abstract}

Keywords: basic education quality management, industrial revolution 4.0, society 5.0

\section{INTRODUCTION}

Industrial Revolution 4.0 is very oriented to the application of technology, meaning that every educational institution must centralize and apply technology as a basis, so that if there is an educational institution that does not immediately implement it can be immediately displaced and even eroded by existing competition. The concept of the Industrial Revolution 4.0 developed has the potential to degrade the role of humans. With this condition, the concept of society 5.0 was born, which was the development of the concept of industrial revolution 4.0, transferring big data collected through the internet in all fields of life, especially in the world of education to improve the quality of teachers.

The development of education in the era of the industrial revolution 4.0 and society 5.0 is inevitable. With the development of this technology, it requires all of us to be ready to face existing disruption of innovation in all lines, including education in the era of globalization, where the era is full of competition for quality or quality in the world of education. Educational institutions in the era of industrial revolution 4.0 and society 5.0 should be based on quality in providing customer education services and human resource development. School institutions must not be quickly satisfied and must continue to innovate to create excellence in order to be able to compete with competitors.

Education in the 21 st century will face more severe challenges than the previous century. Technological advances in the era of industrial revolution 4.0 have developed so rapidly entering classrooms without having to go through social political control, moral control. The development of science and technology has changed the world civilization, as has given birth to history when many human and animal energies were replaced with mechanical power, marked by the emergence of super computers, unmanned vehicles and some without rudders, and super smart robots.

The era of industrial revolution 4.0 has not been fully mastered by educators and students in the implementation to improve the quality of learning outcomes or the quality of graduates, but has entered the era of society or society, for that educational institutions must be able to prepare the quality of graduates to adapt to the flow of educational progress globally, because the role of humans cannot be completely replaced by robots or artificial intelligence.

Society in the era of society 5.0 is a society that can solve various social challenges and problems by utilizing various innovations born in the era of industrial revolution 4.0 such as the Internet of things, big data, robots, and various sophisticated machines, in humanizing humans so that technological advances should be more facilitate human work, because of the various abilities and expertise that society in the era of society 5.0 is also referred to as 'smart society' or intelligent society. Era of society 5.0 or society 5.0 is a necessity that must be faced by the world of education to produce quality or quality that is able to compete.

The birth of the era of society 5.0 was the answer that emerged as a result of the era of industrial revolution 4.0 which was accompanied by disruption marked by a world full of turmoil, uncertainty, complexity and ambiguity. The future of education in the Era of Industrial Revolution 4.0 now, many educational institutions in Indonesia have promoted the spirit of digitalization in various fields. If this digitalization can be handled properly and can be well integrated with the Indonesian 
people, education in Indonesia will be able to transform into a 5.0 society.

\section{METHOD}

Writing this article has the purpose of describing the system of implementing quality assurance in the era of industrial revolution 4.0 and society 5.0. Writing this article using the literature study method, the author looks for references from several reference sources that are considered relevant to a case or problem that was found and studied. Adequacy of reference sources becomes very important in reviewing theories that are relevant to checking between theories with the problems examined by the author.

According to Bungin (2008) literature review method is one method of data collection that is often used in social research methodologies to trace historical data in accordance with the problems examined by researchers. While other opinions according to Sugiono (2005) that literature studies are studies that explore information or data through records of events that have been recorded in a scientific work in the form of writing, images, or monumental works of someone.

To find the right reference to the problem, the author looks for various existing literature to find new reference sources to solve the problems being studied. The purpose of literacy studies is to strengthen conceptual problems to be used as material for theoretical studies in conducting literacy studies and also become the basis of research design on the application of quality management in education in the era of industrial revolution 4.0 and society 5.0 .

\section{RESULTS AND DISCUSSION}

\section{A. The Concept of Education Quality and Education Quality Standards}

\section{Concept of Educational Quality}

Education management has relevance to changes in organizational culture. Organizational quality can be achieved, refined, and developed with the implementation of management systems. The field of education relates to curriculum, teacher competence, structuring of facilities and learning facilities, so that the management system focuses on these aspects. Significant changes will occur if accompanied by improved management patterns and culture that support these changes. According to Sonhadji (2015) management can be defined as the process of utilizing resources and coordinating and integrating activities effectively and efficiently to achieve organizational goals with or through others.

The quality of a country's education system is the main determinant of the quality of the workforce. According to Goetsech (2000) the higher the quality of labor (labor pool), the higher the quality of labor recruitment (entry-level employees). The higher the quality of labor recruitment, the faster they become productive workers and contribute to competition in employment. As a consequence, a high-quality education system is an important component for competitiveness. According to Isjoni (2009) indicators of the progress of a nation are very much determined by the country's human resources. The above implies that one of the criteria for graduates of quality education institutions is the rapid absorption of them in the field of work and their acceptance in institutions of further education.

According to Goetsech (2000) quality lies in the judgment of the person who observes it (beholder). In the approach of integrated quality (total quality) the customer (customer) is the absolute determinant of quality. As an illustration, for example, customers assess the quality of a restaurant in terms of service, food presentation, environmental atmosphere, price, choice menu, and fast presentation.

Although there is no general quality definition that can be accepted by all parties, at least in the quality there are general components, namely: (1) fulfillment of customer expectations; (2) focusing on products, services, people, processes and environment, and (3) ever-changing state. From these three components Goetsch and Davis define quality as a dynamic condition involving products, services, people, processes, and the environment in order to fulfill expectations.

In absolute terms, quality is interpreted as something that is no longer negotiable or absolute. Absolute in the context of quality can also be said as a condition determined unilaterally, namely by the producer. In absolute view, quality is defined as the best measure according to the manufacturer's consideration in producing goods or services. Furthermore, the relative concept of quality is defined as quality in perception (quality in perception). Something is called quality if it satisfies and exceeds customer wants and needs.

This quality can be called quality which only exists in the eyes of the person who sees it. This is a very important definition. Because, there is one risk that is often overlooked from this definition, namely the fact that customers are those who make decisions about quality. Customers make these assessments by referring to the best products that can survive in competition.

According to Sallis (2010) the relative definition of quality has two aspects. First, is to adjust to specifications. Second, is to meet customer needs. The first way, adjusting to specifications, is often concluded in accordance with the objectives and benefits. Sometimes this definition is often called the manufacturer's definition of quality. As long as a product is in accordance with the specifications and factory standards, then the product is a quality product. Such opinions about quality are often referred to as actual quality (quality in fact).

Quality is actually the basis of a quality assurance system that is considered to be in accordance with the British Standard Institution in BS 5750 standards or international standards identical to ISO 9000. According to Mujamil (2007) the meaning of quality in the context of education is defined as a system (input, process, and output).

\section{The Concept of Educational Quality Standards}

The quality concept requires a standard as a definite measure to be achieved in the process of management activities. Some opinions say that quality standards are determined by external parties. Another opinion says that quality standards are determined by internal parties. From this diversity of theories gave birth 
to many quality standards offered, for example Total Quality Management (TQM), Balanced Scorecard, Malcolm Baldridge Award, ISO 9000 series and so on. Especially in Indonesia, for primary and secondary education units using the standards of the National School Accreditation Agency. For universities, the BAN-PT standard is in addition to the aforementioned international standards.

The concept of quality in the field of education is different from industry. The difference lies in the human element which is processed as a result. Therefore, the end of the quality assessment is the quality of graduates. The quality of graduates is very diverse and complex with one another in the same group of graduates. A simple assessment is that if graduates can be accepted to work according to their scientific fields and / or are accepted in leading universities for those who continue their studies, then the educational institutions are considered qualified.

Mu'ti (2015: 14) the quality of education in the education unit has the meaning of producing and giving only the best. In Government Regulation No. 19 of 2005 article 91 states that, every education unit is required to carry out education quality assurance. Educational quality assurance aims to meet or exceed National Education Standards (SNP). Educational quality assurance is carried out in stages, systematically, and planned in a quality assurance program that has a clear target and time frame.

\section{B. Quality Management in Education}

Feigenbaum is a quality management expert who introduced the concept of total quality control. Meanwhile, Ishikawa is a quality management expert from Japan who put forward the concept of quality control circle, company wide quality control, and Ishikawa cause-effect diagram. Broadly speaking, changes in quality movement follow four main understandings, namely: (1) inspection and quality control, (2) quality assurance, (3) total quality management, and 4) global quality management (Darwin 2012).

According to Sukmadinta (2006) the quality of education or school quality is focused on the quality of graduates. It is impossible, education or school produces qualified graduates if not through a quality education process. It is also impossible, a quality education process occurs if it is not supported by the supporting factors of the quality education process. The process of quality education must be supported by personnel, such as administrators, counselor teachers, and quality and professional administration. This is also supported by educational facilities, facilities, media, and adequate learning resources.

Quality control includes steps, namely: (1) assessing the actual quality of the product, (2) comparing products with objectives, and (3) differentiating between products and objectives. Third, quality improvement includes steps, namely: (1) developing quality improvement infrastructure, (2) identifying certain areas that need improvement, (3) designing teamwork for quality improvement, (4) facilitating teams in Bush quality improvement (2012).

\section{Principles and Components of Quality Management in Education}

According to Hensler and Brunnell in Nasution (2001) outline the principles of integrated quality management (TQM), namely: changing the view that educational institutions are not just industries that process and print but try to focus on the wants and needs of current and future customers, quality improvement continues planned and continuous improvement, planning to achieve the expected quality / step strategy, focus on improving and developing human resources, attachment to the work outcome that continues to increase.

Furthermore, the focus of quality or quality assurance in schools is: (1) the focus of students, because each child with the character and uniqueness of each that needs to be served to develop their talents and intelligence, (2) focus on achievement or results, the school always determines the target of high achievement towards learning outcomes of students, so as to provide satisfaction to stakeholders. The quality of student learning outcomes is determined by how much the target is achieved. School institutions should continue to make improvements to the expected quality improvement, (3) focus on branding, all the resources and efforts made to continue to build creativity and innovation and learning activities in schools. Building branding is done by compiling benchmarks. Benchmarking continues to be pursued in the face of very competitive competition in the world of education.

Scientific steps continue to be pursued systematically and planned to ensure the quality of graduates, (4) the focus of long-term commitment, education is not only to answer today's challenges, but furthermore how education is able to prepare students during their time. Quality is not easily achieved in a moment, to get the desired quality requires hard work from all stakeholders in the school. Safe, comfortable conditions conducive to guaranteeing the implementation of quality assurance will work well, (5) the focus of team work, carried out in an effort to realize the shared ideals. Success requires hard work from all elements in the school environment. Principals, education boards, education administration staff, and students must be fully involved in the implementation of learning, (6) innovative focus, schools continue to make efforts to improve and seek new breakthroughs in facing the development of the world and science. Schools continue to innovate to produce quality and competitive graduates, (7) focus on creating creativity in learning, students as subjects in schools are also given space to be creative as self and emotional maturation but still in the guidance of the teachers. With the hope that it can foster an independent and responsible spirit and a sense of belonging to realize common goals in education, (8) focus on shared ideals, educational institutions always apply well cooperation among all components starting from the security guard to the most behind (cleaning staff), educational institutions must have a unified goal in organizing all their potential.

Sulaiman (2016) stated his ideals, hopes for the quality of a graduate need a quality assurance system so that the quality of graduates can be improved continuously. While Sukmadinata (2006) states the 
quality of schools can be measured by how much the graduates produced are absorbed in the next level of school and accepted in the world of work. Sallis (2010) reveals that the product is said to have quality or quality if it meets two elements, that is, it can meet customer desires and expectations and set high specifications.

\section{Steps for Education Quality Management}

Lahmuddin Lubis (2014) explained that in relation to efforts to develop and improve the quality of education, there are four perspectives in the development of the education sector. First, the perspective of education equality (equality of educational opportunity). This perspective emerged in the early 1960 s by looking at education as a means to improve equitable distribution of people's welfare; with the note that educational opportunities that are increasingly evenly distributed are factors that can bring about more equitable welfare. Second, education perspective and achievement of one's position (education and status attainment). This perspective began to emerge in the late 1960s and has carried out studies of education in relation to increasing one's status and position in society. The approach used in this perspective is education and employment (manpower requirement approach) which directs its analysis of the balance between the supply and needs of educated labor in various economic sectors.

Third, the human capital perspective. This perspective emphasizes the function of education in spurring national economic growth through increased mastery of skills, expertise, professions, and scientific mastery that can make workers more productive. One model of study in this perspective includes the rate of return to education that directs attention to labor productivity and economic growth.

Fourth, the education and human resource development perspective. This perspective has emerged since the issue of economic miracle in a number of countries in the East Asian region arose as a result of the growth of the industrial economy and professionalization. In this regard, the idea of the quality of human resources in relation to industrial productivity in the context of world competition has developed since the agreement of the WTO (world trade organization) and the issue of global competition and free markets emerged both regionally and internationally.

From the four perspectives above, the speakers concluded that philosophical and integrated quality management concepts (total quality management) are implications from the perspective of education and human resource development. Therefore, the relationship of quality, education and human resource development in the current era is a necessity.

Furthermore, the quality management of education in schools according to Law Number 20 Year 2003 concerning National Education System (UUSPN) article 51 paragraph (1) states that the management of early childhood education, basic education and secondary education is carried out based on minimum service standards with the principle school / madrasah based management. This UUSPN affirmation is reinforced by Government Regulation Number 19 of 2005 article 49 paragraph (1) stating that the management of education units at the primary and secondary education level implements school-based management as indicated by independence, partnership, participation, openness, and accountability.

Secondly, the principal and the teacher have the same profession, namely the teacher's background. System of coordination between school principals and teachers. The system of coordination between principals and teachers sometimes becomes mutually rubbing not as superiors and subordinates as in the company.

Third, schoolmanagement faces fragmentative problems, so that school decision making is largely influenced by external parties, such as student guardians, government, and employment. These elements are outside and very diverse in interests, not within the management of the school, so interest is difficult to avoid.

Fourth, school principals have teaching assignments that often become busy, so they have less time to carry out school quality management. Duplicate tasks often lead to not optimal tasks, because the tasks with each other cannot be clearly defined. Being a teacher must be professional, as well as being a school must be professional. Professionals in two fields simultaneously often become obstacles. Fifth, students on the one hand as customers must be given the best education and learning services, but on the other hand as humans they can determine their own best choices. Human formation is not the same as forming easily engineered items into new forms

\section{E. Quality Management in the Era of Industrial Revolution 4.0 and Society 5.0}

Revitalization of learning systems includes: (1) curriculum and character education, (2) information and communication technology-based learning materials, (3) entrepreneurship, (4) alignment, and (5) evaluation. Educational units include: (1) new school units and new classrooms, (2) other study rooms, (3) rehabilitation of classrooms, (4) student dormitories and teachers, (5) equipment, and 6) school management and culture.

Elements of students include: (1) giving scholarships and (2) developing interest talents. Elements of educators and education personnel include: (1) provision, (2) distribution, (3) qualifications, (4) certification, (5) training, (6) career and welfare, and (7) appreciation and protection. Strengthening the four elements in the education system requires a new movement to respond to the industrial era 4.0. One of the movements proclaimed by the government was a new literacy movement as a reinforcer and even shifted the old literacy movement. The new literacy movement is intended to focus on three main literacies namely: (1) digital literacy, (2) technology literacy, and (3) human literacy (Aoun, 2017).

These three skills are predicted to be skills that are needed in the future or in the industrial era 4.0. Digital literacy is aimed at improving the ability to read, analyze, and use information in the digital world (Big Data), technology literacy aims to provide an understanding of the workings of machinery and the application of technology, and human literacy is directed at improving 
communication skills and mastery of Aoun's design knowledge (2017) The new literacy provided is expected to create graduates who are competitive by perfecting the old literacy movement which only focuses on improving reading, writing and math skills. Adaptation of the new literacy movement can be integrated by adjusting the curriculum and learning system in response to the industrial era 4.0.

According to Trillling and Fadel (2009), 21st century learning is oriented towards digital lifestyles, thinking tools, learning research and how knowledge works (see figure 3). Three of the four 21st century learning orientations are very close to vocational education, namely how to work knowledge, strengthening thinking tools, and digital lifestyle. The workings of knowledge are the ability to collaborate on teams with different locations and with different tools, strengthening thinking tools is the ability to use technology, digital tools, and services, and digital lifestyle is the ability to use and adapt to the digital era (Trilling \& Fadel, 2009). World economic forum launches, the 21 st century skill structure will experience change. In 2015, the skills structure was as follows; (1) complex problem solving; (2) cooperation with others; (3) management of people; (4) critical thinking; (5) negotiations; (6) quality control; (7) service orientation; (8) assessment and decision making; (9) listen actively; and (10) creativity.

In 2020 the work structure changed to: (1) complex problem solving; (2) critical thinking; (3) creativity; (4) management of people; (5) cooperation with others); (6) emotional intelligence; (7) assessment and decision making; (8) service orientation; (9) negotiations; and (10) cognitive flexibility (Irianto, 2017). All forms of skills and skills in the 21 st century and the required industrial era 4.0 must be integrated into the elements of vocational education. Starting from the learning system, educational units, students, to educators and education staff.

Human Resources to Improve Education Quality in the Era of Industrial Revolution 4.0 and Society 5.0. As a very new concept in the midst of the world education community in particular, society will change the concept of industrial revolution 4.0 which has the potential to degrade the role of humans. For this reason, the whole world is reminded by the Japanese state of the importance of the element of human resources as the backbone of every educational institution. The era of society 5.0 also reminds all parties to be able to apply the concept of society 5.0 by being based on certain wisdom on the human element, so that our lives will be more meaningful. The important thing to do by educators, especially in learning is to be able to change the way of thinking in designing, implementing and evaluating learning, because the era of industrial revolution 4.0 and Society 5.0 requires superior and reliable human resources according to the needs of the business world and the industrial world. With superior human resources in the future, it will be able to create graduates who can compete in the era of the Industrial Revolution 4.0. In an era of rapid technological developments that have influenced the world of education, teachers have difficulty competing with machines or robots that are present far smarter, faster, and more effective in seeking information and knowledge. Therefore the teacher must be willing to change the traditional teaching method into a multistimulant learning so that learning is more fun and interesting.

The role of the teacher in the era of industrial revolution 4.0 and society 5.0 must be changed which initially the role of the teacher as the person who knows best and the knowledge provider becomes; mentor, facilitator, motivator, inspiration and also the developer of imagination after creativity, then the teacher becomes a planter of character values and builds team work and social empathy. Facing industrial revolution 4.0 and society 5.0 there will be a change and the key to change is education to increase human resources.

The industrial revolution 4.0 brought many changes in human life. Industry 4.0 has fundamentally changed the way people move and has a big influence on the world of work. The positive influence of industry 4.0 is in the form of effectiveness and efficiency of resources and production costs even though it has an impact on reducing employment. Industry 4.0 requires workers who have skills in digital literacy, technology literacy, and human literacy. Education must be able to equip graduates with these three literacies through revitalizing the chrono system which includes learning systems, educational units, students, and educators and education staff. To realize 5.0 society in Indonesia there are three things that must be done so that the concept of Industrial revolution 4.0 can realize 5.0 society, namely: (1) Must be able to change the mental leaders and society to be able to think positively about technological development, (2) Must promote a digital innovation culture for millennials, (3) must give awareness to the public, that we cannot forever depend on natural resources, but must strengthen Human Resources and Knowledge because future wars are a war of thoughts

\section{F. Competencies of Society Era 5.0}

In winning the competition and preparing school graduates ready to face the era of 5.0 society. the schools should prepare their students to have 4 competencies as stated by the Chancellor of IPB (Kompas.com), namely: leadership, linguage skills, IT literacy, writing skills.

Leadership, students should be equipped with leadership skills so that they have strong character regardless of the progress of technological developments and information, they will not dissolve in the flow of progress that is difficult to stem but they are able to play a role with the entry of the existing development era. able to take advantage of every moment of the development of the flow of developing science and technology.

Language skills, foreign language skills become an important capital that must be controlled by students, in the millennial era, all of which are not accessible to foreign language mastery becomes an unavoidable demand to be able to play a role in the ability of science and information technology. By mastering foreign languages, students can interpret every developmental flow as a subject, not just being the object of the development of the flow of science and technology. 
IT Literacy, IT development characterizes 5.0 people. students should continue to improve their abilities every time there are developments in science and technology by reading and studying every development that is so fast.

Important skills, abilities and skills to be mastered by students are writing skills, with writing skills so students can contribute by pouring ideas, ideas in the era of society 5.0 .

\section{CONCLUSION}

The development of science and technology in the era of industrial revolution 4.0 and society 5.0 greatly changed the paradigm of mankind to not only become objects that were exploited by the flow of globalization. The development of the industrial revolution era 4.0 and society 5.0 also had positive and negative effects. The negative impact in the industrial era 4.0 was to replace human and animal power with sophisticated machines or robots, so that humanity was less human, one of which was seen in several industrial aspects that had implemented computer systems to replace human labor, while the positive impact was that people could work anywhere at home using a computer to make money.

Based on the results of the above conclusions, several suggestions can be submitted: (1) leaders or principals are able to change the mentality of educators and education so that they always think positively towards every technological development in the era of Industrial Revolution 4.0 and society 5.0; and (2) the principal of the mamapu motivates educators to always innovate to improve their abilities and professionalism during the Revolution era Industry 4.0 and society 5.0 for the creation of quality education quality.

\section{REFERENCES}

[1] Aoun, J.E. (2017). Robot-proof: Higher Education In The Age Of Artificial Intelligence. US: MITPress

[2] Bungin, B. (2008). Penelitian Kualitatif: Komunikasi, Ekonomi, Kebijakan Publik dan Ilmu Sosial Lainnya. Jakarta: Kencana
[3] Bush, T. \& Marine C. (2012). Manajemen Mutu Kepemimpinan Pendidikan: Panduan Lengkap Kurikulum Dunia Pendidikan Modern. Yogyakarta: IRCiSoD.

[4] Darwin, I. (2012). Penjamin Mutu Pendidikan dan Pengawasan Medan, Unimed Press.

[5] Goetsech D. L. \& Stanley B. D. (2000). Quality Management: Introduction to Total Quality Managemen for production, and Services. New Jersey: Prentice-Hall, Edisi III

[6] Irianto, D. (2017). Industry 4.0: The Challenges of Tomorrow. Seminar Nasional Teknik Industri, BatuMalang.

[7] Isjoni. (2009). Menuju Masyarakat Belajar: Pendidikan dalam Arus Perubahan Yogyakarta: Pustaka Pelajar.

[8] Kompas.com. 2019. 4 Kompetensi Lulusan Jadi Kunci Society 5.0. retrieved 23 July 2019, from http://edukasi.kompas.com/read/2019/03/20/213991851.

[9] Lubis L. (2014). Dalam penjelasan matakuliah Perencanaan Strategi Pendidikan. Januari.

[10] Mu'ti. A. (2015). Pedoman Akreditasi Sekolah: Akreditasi Bermutu Untuk Pendidkan Bermutu. Jakarta: Badan Akreditasi Nasional Sekolah.

[11] Nasution, M. N. (2001). Manajemen Mutu Terpadu (Total Quality Management). Jakarta: Ghalia Indonesia

[12] Peraturan Pemerintah R.I Nomor 19 Tahun 2005 Tentang Standar Nasional Pendidikan.

[13] Sallis, E. (2010). Manajemen Mutu Terpadu Pendidikan: Peran Strategis Pendidikan di Era Globalisasi Modern. Yogyakarta: IRCiSoD.

[14] Sonhadji, A \& Muhammad H. A.Y. (2015). Asesmen kebutuhan, Pengambilan keputusan, dan perencanaan: Mata rantai dalam Manajemen Pendidikan. Malang: Penerbit Universitas Negeri Malang (UM Press).

[15] Sugiono. (2005). Memahami Penelitian Kualitatif. Bandung: Alfabeta

[16] Sukmadinata N, Ayi N, Jami'at, A. (2006). Pengendalian Mutu Sekolah Menengah: Konsep, Prinsip, dan Instrumen. Bandung: Refika Aditama.

[17] Sulaiman, A., \& Wibowo, U.B. Implementasi Sistem Penjaminan Mutu Internal, Sebagai Upaya Meningkatkan Mutu Pendidikan Di Universitas Gadjah Mada. Jurnal Akuntabilitas Manajemen Pendidikan. Vol 4, No 1, April 2016 (17-32)

[18] Trilling, B \& Fadel, C. 2009. 21st-Century Skills: Learning For Life In Our Times. US: Jossey-Bass A Wiley Imprint.

[19] Undang-Undang R.I. Nomor 20 Tahun 2003 tentang Sistem pendidikan Nasional 